\title{
SISTEM PAKAR UNTUK MENDIAGNOSIS PENYAKIT LAMBUNG DAN PENANGANANNYA MENGGUNAKAN METODE DEMPSTER SHAFER
}

\author{
Kirman $^{1}$, Andika Saputra ${ }^{2}$, Jacky Sukmana ${ }^{3}$ \\ ${ }^{1,2}$ Program Studi Sistem Informasi, Fakultas Teknik, Universitas Muhammadiyah Bengkulu \\ ${ }^{3}$ Lembaga Pengembangan Teknologi Informasi dan Komunikasi, Universitas Bengkulu \\ ${ }^{1} \mathrm{kirmandumb} \cdot \mathrm{ac} \cdot \mathrm{id}$ \\ ${ }^{2}$ dikalgmail.com \\ 3jacky-sukma@unib.ac.id
}

Abstrak: Sistem pakar (Expert System), merupakan salah satu cabang Artificial Intelligence (AI), Salah satu jenis sistem pakar dalam bidang kesehatan adalah sistem pakar untuk mendiagnosis penyakit lambung berdasarkan gejala atau keluhan yang dirasakan oleh pasien. Penyakit pada lambung antaralain adalah sakit maag (Gastritis), Dispepsia dan Gastroesophageal Reflux Disease (GERD). Penyakit maag diakibatkan oleh asam lambung yang berlebihan, sehingga dinding lambung lama-lama tidak kuat menahan asam lambung tadi sehingga timbul luka. Sistem pakar penyakit lambung ini menggunakan teori Dempster-Shafer, karena dengan teori tersebut dapat mengetahui persentase kemungkinan penyakit yang diderita pasien dan diharapkan sistem dapat memberikan saran untuk melakukan tindakan atau pengobatan yang sesuai dengan jenis penyakitnya. Dempster-Shafer adalah representasi, kombinasi dan propogasi ketidakpastian, dimana teori ini memiliki beberapa karakteristik yang secara instutitif sesuai dengan cara berfikir seorang pakar, namun dasar matematika yang kuat. Berdasarkan tabel hasil penelitian bisa disimpulkan bahwa hasil dari Dokter dengan Sistem pakar penyakit lambung dengan metode dempster shafer berbasis web ini mempunyai kecocokan atau kesesuaian sebesar $70 \%$.

Kata Kunci: Penyakit Lambung, Sistem Pakar, Dempster Shafer

\begin{abstract}
Expert systems are computer-based systems that use knowledge, facts and reasoning techniques to solve problems that can usually be solved only by an expert in a particular field. Salmonella is the main bacterial cause of foodborne diseases. In general, serotypes of Salmonella cause disease in the gastrointestinal organs, infection of Salmonella bacteria can attack the digestive tract that includes the stomach, small intestine, and colon. Diseases caused by Salmonella bacteria are typhoid or typhoid fever, diarrhea and dysentery. There are still many peoplle who do not know the symptoms of this bacterial infection and how to diagnose with a high degree of certainty. To be able to know the level of certainty of bacterial infection this researcher use Dempster-Shafer method. This method is used to calculate the confidence value of the patient's selected symptoms by comparing each weighted value of the two initial
\end{abstract}

symptoms selected for later than the weight value of other symptoms, resulting in new symptoms advocating a disease with the value degree of certainty or belief. The result of this research is to create an expert system application that can diagnose diseases caused by Salmonella bacteria as many as 3 types of diseases that are typhoid, diarrhea and dysentery along with solution or drug treatment and use Dempster Shafer method to get the trust value in the percentage of the disease diagnosis.

Keywords: Expert System, salmonella bacteria, Dempster-Shafer.

\section{Pendahuluan}

Pada zaman sekarang ini perkembangan teknologi komputer telah mengalami perkembangan yang sangat cepat yang mendorong 
Jurnal Pseudocode, Volume V Nomor 2, September 2018, ISSN 2355-5920, e-ISSN 2655-1845 www.ejournal.unib.ac.id/index.php/pseudocode

penggunaan dan pemanfaatan perkembangan teknologi tersebut secara luas di berbagai bidang, salah satunya pada bidang kedokteran atau kesehatan. Dalam perkembangannya komputer mempunyai beberapa fungsi, salah satu fungsinya adalah komputer dapat berlaku menyerupai seorang pakar tau ahli. Pengimplementasian sistem pakar pada bidang kedokteran atau kesehatan dapat berupa diagnosis penyakit, dan pemberian saran penentuan solusi dari hasil diagnosis yang ada.

Menurut Giarratano dan Riley mendefinisikan sistem pakar sebagai sistem komputer yang mampu menirukan kemampuan seorang pakar dalam mengambil keputusan. Sistem pakar sebagai kecerdasan buatan, menggabungkan pengetahuan dan fakta-fakta serta teknik penelusuran untuk memecahkan permasalahan yang secara normal memerlukan keahlian dari seorang pakar. Tujuan utama pengembangan sistem pakar adalah mendistribusikan pengetahuan dan pengalaman seorang pakar ke dalam sistem komputer [1].

Salah satu bakteri yang dapat menimbulkan penyakit adalah bakteri Salmonella. Salmonella adalah bakteri gram negatif, berbentuk spora yang memfermentasi glukosa menjadi Enterobacteria Penyakit tersebut dapat disebarkan melalui makanan yang terkontaminasi bakteri. Salmonella menyerang saluran pencernaan yang mencakup perut, usus halus, usus besar atau kolon yang menyebabkan rasa sakit pada organ pencernaan manusia. Bakteri salmonella dapat menyebabkan berbagai macam penyakit diantaranya demam tifoid (tifus), diare dan disentri. Masih banyak orang yang belum mengetahui gejala-gejala dari infeksi atau penyakit yang disebabkan bakteri Salmonella ini serta bagaimana cara untuk mendiagnosis dengan nilai kepastian yang tinggi terhadap suatu penyakit, sehingga perlu adanya suatu sistem pakar untuk mendiagnosis penyakit akibat bakteri Salmonella beserta saran pengobatannya sesuai medis.

Kemampuan sistem pakar dalam mendiagnosis suatu gejala memang tidak sebaik seorang dokter ahli, masih banyak hal yang tidak pasti atau tidak konsisten yang dapat menyebabkan kemungkinan kesalahan diagnosis. Ketidak konsistenan ini dapat menyebabkan ketidakpastian hasil diagnosis sistem dan menjadi sebuah pertanyaan baru tentang besarnya persentasi kepastian hasil tersebut. Perhitungan ketidakpastian sangat diperlukan dalam system pakar, agar hasil diagnosis dapat mendekati diagnosis seorang pakar atau ahli.

Metode Perhitungan ketidakpastian sistem pakar dapat dilakukan dengan beberapa metode, salah satu metode yang dapat digunakan adalah metode Demspter Shafer. Metode ini diharapkan dapat menghasilkan diagnosis yang lebih tepat dan mempunyai kepastian yang lebih kuat tanpa adanya perubahan ataupun penambahan pada pengetahuannya. Berdasarkan latar belakang masalah tersebut, maka akan dibuat "Sistem Pakar Untuk Mendiagnosis Penyakit Akibat Bakteri Salmonella dan Penanganannya Menggunakan Metode Dempster Shafer".

\section{LANDASAN TEORI}

\section{A. Konsep Dasar Sistem Pakar}

Sistem pakar adalah suatu program computer yang dirancang untuk mengambil keputusan seperti keputusan yang diambil oleh seorang atau beberapa orang pakar. Pakar yang dimaksud disini adalah orang yang mempunyai keahlian khusus yang dapat menyelesaikan masalah yang tidak dapat diselesaikan oleh orang awam [2].

Sebagai contoh, dokter adalah seorang pakar yang mampu mendiagnosis penyakit yang diderita 
Jurnal Pseudocode, Volume VI Nomor 1, Februari 2019, ISSN 2355-5920, e-ISSN 2655-1845 www.ejournal.unib.ac.id/index.php/pseudocode

pasien serta dapat memberikan penatalaksanaan terhadap penyakit tersebut, tidak semua orang dapat mengambil keputusan mengenai diagnosis dan memberikan penatalaksanaan suatu penyakit. Contoh lain, montir adalah seorang yang mempunyai keahlian dan pengalaman dalam menyelesaikan kerusakan mesin. Untuk membangun sistem yang difungsikan untuk menirukan seorang pakar, sistem pakar harus bias melakukan hal-hal yang dapat dikerjakan oleh para pakar. Untuk membangun sistem yang seperti itu maka komponen-komponen dasar yang minimal harus dimiliki adalah sebagai berikut [3]:

1. Antar muka (user interface).

2. Basis Pengetahuan (Knowledge base).

3. Mesin Inferensi (Inference Engine).

\section{B. Basis Pengetahuan (Knowledge Base)}

Knowledge Base (basis pengetahuan) merupakan inti dari program sistem pakar karena basis pengetahuan itu merupakan presentasi pengetahuan atau knowledge representation.basis pengetahuan adalah sebuah basis data yang menyimpan aturan-aturan tentang suatu domain knowledge/ pengetahuan tertentu.

\section{Mesin Inferensi}

Mesin inferensi merupakan komponen system pakar yang memanipulasi dan mengarahkan pengetahuan dari basis pengetahuan, sehingga tercapai kesimpulan. Tugas utama dari mesin inferensi adalah menguji fakta dan kaidah serta menambah fakta baru jika memungkinkan serta memutuskan perintah sesuai dengan hasil penalaran yang telah dilaksanakan. Ada dua metode yang digunakan mesin inferensi dalam mencari kesimpulan atau solusi yaitu:
1. Forward chaining (Pelacakan ke depan) merupakan metode pencarian yang memulai proses pencarian dari sekumpulan data atau fakta, dari fakta-fakta tersebut dicari suatu kesimpulan yang menjadi solusi dari permasalahan yang dihadapi.

2. Backward chaining (Pelacakan ke belakang)

Runut balik merupakan metode pencarian yang arahnya kebalikan dari runut maju. Proses pencarian dimulai dari tujuan, yaitu kesimpulan yang menjadi solusi dari permasalahan yang dihadapi.

\section{Metode Dempster Shafer}

Menurut Sulistyohati dkk (2008) secara umum teori Dempster-Shafer ditulis dalam suatu interval [Belief, Plausability]. Belief (Bel) adalah ukuran kekuatan evidence dalam mendukung suatu himpunan proposisi. Jika bernilai 0 maka mengindikasikan bahwa tidak ada evidence, dan jika bernilai 1 menunjukkan adanya kepastian. Plausibility $(P l)$ ditulis dalam persamaan sebagai berikut [4]:

$$
P l(s)=1-\operatorname{Bel}(-s)
$$

Plausibility juga bernilai 0 sampai 1. Jika kita yakin $-\mathrm{s}$, maka dapat dikatakan bahwa "Bel $=(-\mathbf{s})=0$ ”. Pada teorema Dempster-Shafer kita mengenal adanya frame of discernment yang dinotasikan dengan " $\theta$ ". Frame ini merupakan semesta pembicaraan dari sekumpulan hipotesis sehingga sering disebut dengan environment.

$\theta=\{\theta 1, \theta 2, \ldots \theta n\}$ dimana: $\theta=$ Frame of discernment / environment.

$\theta 1, \theta 2, \ldots \theta n=$ elemen $/$ unsur bagian dalam environment.

Misalkan: $\theta=\{\mathrm{A}, \mathrm{F}, \mathrm{D}, \mathrm{B}\}$ 
Jurnal Pseudocode, Volume V Nomor 2, September 2018, ISSN 2355-5920, e-ISSN 2655-1845 www.ejournal.unib.ac.id/index.php/pseudocode

Dengan:

$$
\begin{aligned}
& \mathrm{A}=\text { Alergi; } \\
& \mathrm{F}=\text { Flu; } \\
& \mathrm{D}=\text { Demam; } \\
& \mathrm{B}=\text { Bronkitis } .
\end{aligned}
$$

Tujuan kita adalah mengkaitkan ukuran kepercayaan elemen-elemen $\theta$. Tidak semua evidence secara langsung mendukung tiap-tiap elemen. Sebagai contoh, panas mungkin hanya mendukung (F, D, E). Untuk itu perlu adanya probabilitas fungsi densitas (m). Nilai m tidak hanya mendefinisikan elemen-elemen $\theta$ saja. Namun juga semua subsetnya. Sehingga jika $\theta$ berisi $\mathrm{n}$ elemen, maka subset dari $\theta$ semuanya berjumlah $2^{\mathrm{n}}$. Kita harus menunjukkan bahwa jumlah semua $m$ dalam subset $\theta$ sama dengan 1 .

Andaikan tidak ada informasi apapun untuk memilih keempat hipotesis tersebut, maka nilai: $\mathrm{m}$ $(\theta)=1,0$ Jika kemudian diketahui bahwa panas merupakan gejala dari flu, demam dan bronchitis dengan $\mathrm{m}=0,8$ maka:

$$
\begin{aligned}
& m(\mathrm{~F}, \mathrm{D}, \mathrm{B})=0,8 \\
& m(\theta)=1-0,8=0,2
\end{aligned}
$$

Andaikan diketahui $X$ adalah subset dari $\theta$, dengan $\mathrm{m}_{1}$ sebagai fungsi densitas, dan $Y$ juga merupakan subset dari $\theta$ dengan $m_{2}$ sebagai fungsi densitasnya, maka kita dapat membentuk pangan mentah, seperti telur dan daging ayam mentah serta akan bereproduksi bila proses pamasakan tidak sempurna. Sakit yang diakibatkan oleh bakteri Salmonella dinamakan Salmonella. Penderita yang mengalami Salmonella dapat menunjukkan beberapa gejala seperti diare, keram perut, dan demam dalam waktu 8-72 jam setelah memakan makanan yang terkontaminasi oleh Salmonella. Gejala lainnya adalah demam, sakit kepala, mual dan muntah-muntah [5].

\section{METODE PENELITIAN}

\section{A. Metode Pengumpulan Data}

Adapun teknik pengumpulan data yang dilakukan pada penelitian ini, diantaranya:

\section{Interview (wawancara)}

Penulis melakukan interview (wawancara) terhadap pihak yang berkompeten khususnya dokter yang bertugas di RSUD Curup yaitu Petugas Laboratorium (Mike) dan Dokter Spesialis Dalam (dr. Melindah, Sp.PD) untuk mendapatkan penjelasan dari masalah-masalah yang sebelumnya kurang jelas dan untuk menyakinkan bahwa data yang diperoleh/dikumpulkan benar- benar akurat.

\section{Studi Pustaka}

Metode ini penulis mengutip dari beberapa bacaan yang berkaitan dengan sistem pakar Untuk mendiagnosis penyakit akibat bakteri Salmonella dan pelaksanaan penelitian yang dilaksanakan di RSUD Curup, baik dari buku, artikel, dokumen ataupun jurnal ilmiah.

\section{B. Metode Pengembangan Sistem}

Metode pengembangan yang digunakan penulis dalam penelitian ini yaitu menggunakan metode RUP (Rational Unified Process), yaitu suatu metode rekayasa perangkat lunak yang pengembangan perangkat lunaknya dilakukan secara berulang-ulang (iteratif). Dalam metode ini, terdapat empat tahap/ fase pengembangan perangkat lunak, yaitu:

a. Inception (Permulaan)

Tahap inception memiliki tahapan analisis sistem yaitu dengan mengidentifikasi masalah dan kebutuhan, mendefinisikan batasan masalah, memahami sistem yang sedang berlangsung, menganalisis sistem usulan dan membuat laporan analisis. 
Jurnal Pseudocode, Volume VI Nomor 1, Februari 2019, ISSN 2355-5920, e-ISSN 2655-1845 www.ejournal.unib.ac.id/index.php/pseudocode

\section{b. Elaboration (Perluasan/Perencanaan)}

Pada tahap ini lebih difokuskan pada perencanaan arsitektur sistem. Langka -langkah yang dilakukan penulis pada tahap ini meliputi perancangan database, perancangan basis pengetahuan sistem pakar diagnosis penyakit akibat bakteri Salmonella serta perancangan antarmuka aplikasi.

c. Construction (Konstruksi)

Tahap ini fokus pada pengembangan komponen dan fitur yang ada pada sistem. Tahap ini lebih pada implementasi dan pengujian sistem yang fokus pada implementasi perangkat lunak pada kode program. Langkah-langkah yang dilakukan meliputi pembuatan tampilan layout pada android studio, penulisan kode program.

\section{d. Transition (Transisi)}

Tahap ini lebih pada deployment atau intalasi sistem yang sudah berhasil dibuat agar dapat dimengerti oleh user. pada tahap ini yang dilakukan penulis meliputi pengujian sistem aplikasi dan sosialisasi aplikasi kepada pengguna

\section{ANALISIS DAN PEMBAHASAN}

\section{A. Analisis Kebutuhan Sistem}

Analisis kebutuhan system yang akan dirancang disesuaikan dengan analisis kebutuhan user. analisis kebutuhan sistem meliputi:

\section{Data Masukan (input)}

Data masukan yang diperlukan berupa data penyakit, gejala, solusi/ obat penanganannya, aturan gejala, aturan solusi dari penyakit. Data penyakit diperlukan karena merupakan inti dari pengetahuan yang akan digunakan sebagai tujuan diagnosis. Data gejala merupakan data yang ditunjukkan atau yang akan dipilih oleh user. Pada data gejala juga disertai dengan nilai probabilitas yang diperoleh dari pakar. Data diagnosis dan solusi merupakan data yang digunakan sebagai saran dari user. Sistem yang dibutuhkan untuk spesifikasi data masukan (input):

a. Data penyakit diperlukan karena merupakan inti dari pengetahuan yang akan digunakan sebagai tujuan pendiagnosisan.

b. Data gejala merupakan data yang akan dipilih oleh user sebagai input-an ke sistem. Pada data gejala juga disertai dengan nilai probabilitas dari gejala tersebut.

c. Data solusi merupakan data yang berisi solusi penyakit.

d. Data aturan gejala merupakan data aturan relasi dari gejala-gejala dengan suatu penyakit.

e. Data aturan solusi merupakan data aturan relasi dari solusi-solusi dengan suatu penyakit.

\section{Data Keluaran (Output)}

Sistem yang dirancang dapat memberikan output yaitu dapatmenampilkan kemungkinan penyakit dari hasil diagnosis, dapat menampilkan nilai persentase penyakit (derajat kepercayaan) dan dapat menampilkan solusi atau obat penanganannya sesuai dengan penyakit hasil diagnosis.

3. Proses

Data yang akan diproses menjadi hasil diagnosis bermula ketika user memilih gejala yang dirasakan (dengan menjawab "YA"), gejala tersebut akan diproses oleh system dengan pelacakan forward chaining berdasarkan dengan metode Dempster-Shafer untuk menemukan penyakit yang diderita oleh pasien. Metode ini akan membandingkan tiap gejala dengan penyakit yang ada dan menghitung kepastiannya sampai diperoleh nilai yang tertinggi yang merupakan hasil diagnosis. Hasil proses berupa diagnose nama penyakit yang kemungkinan diderita pasien (user) dengan nilai persentase nilai kepastian penyakit tersebut. 
Jurnal Pseudocode, Volume V Nomor 2, September 2018, ISSN 2355-5920, e-ISSN 2655-1845 www.ejournal.unib.ac.id/index.php/pseudocode

\section{B. Basis Pengetahuan}

Sistem pakar ini membutuhkan pengetahuan dan mesin informasi untuk mendiagnosis penyakit yang di alami pasien. Basis pengetahuan merupakan kumpulan-kumpulan fakta. Adapun data yang ada di dalam basis pengetahuan diperoleh dari Pakar yaitu petugas Laboratorium (Mike Rezeki) dan Dokter Spesialis Dalam (dr. Melindah, Sp.PD) RSUD Curupaten Rejang Lebong juga diperoleh dari buku, artikel, dan situs internet. Basis pengetahuan ini berisikan faktorfaktor yang dibutuhkan oleh sistem yaitu sebagai berikut:

Tabel 1. Basis Pengetahuan Gejala-gejala Penyakit

\begin{tabular}{|l|l|}
\hline Kode & \multicolumn{1}{|c|}{ Nama Gejala } \\
\hline G1 & Lemas/Lesu \\
\hline G2 & Mual, Muntah \\
\hline G3 & Sakit perut / Perut Kram \\
\hline G4 & Sakit Kepala / pusing \\
\hline G5 & Demam / Panas \\
\hline G6 & Mulut Kering, Bibir pecah-pecah \\
\hline G7 & Perut Kembung \\
\hline G8 & Ruam di tubuh \\
\hline G9 & Feses Encer dan berlendir \\
\hline G10 & BAB >=4x Sehari \\
\hline G11 & Suhu Tubuh Naik Turun \\
\hline G12 & Merancau / menggigau \\
\hline G13 & Perut Mulas \\
\hline G14 & Nadi lemah \\
\hline G15 & Sembelit/ Konstipasi \\
\hline G16 & Feses Berdarah \\
\hline G17 & Titer Widal Antigen H/O/H-A <=1/160 \\
\hline G18 & Sakit saat Buang Air Besar \\
\hline G19 & Batuk kering \\
\hline G20 & Penurunan berat badan \\
\hline G21 & Kehilangan nafsu makan \\
\hline G22 & Mengalami Linglung \\
\hline G23 & Nyeri dan sakit pada otot \\
\hline G24 & Feses yang dihasilkan banyak \\
\hline G25 & Haus terus menerus \\
\hline & \\
\hline
\end{tabular}

Tabel 2. Basis Pengetahuan Penyakit akibat Bakteri Salmonella

\begin{tabular}{|c|l|l|}
\hline Kode & Penyakit & \multicolumn{1}{c|}{ Saran Pengobatan } \\
\hline \multirow{6}{*}{ P1 } & & Penggunaan Antibiotik \\
& & (harus dengan resep dokter): \\
& & - Amoxilin \\
& & - Chloramphenicol \\
& & - Ciprofloxacin (Cipro) \\
& Tipes & Obat Tradisional/Herbal: \\
& & - Memakan Bawang putih \\
& & - Minum rebusan Air \\
& & Cengkeh \\
& & - Minum Jus Jambu Merah \\
& & - Makan Telur Rebus \\
& & - Mengkonsumsi Madu, \\
& & Jeruk, Mentimun, Pisang \\
\hline
\end{tabular}

\begin{tabular}{|c|c|c|}
\hline & & $\begin{array}{l}\text { Penggunaan Obat Apotik: } \\
\text { - } \quad \text { Oralit (untuk pencegahan } \\
\text { resiko dehidrasi) } \\
\text { - } \quad \text { Loperamide (obat anti } \\
\text { diare) } \\
\text { - }\end{array}$ \\
\hline $\mathrm{P} 2$ & Diare & $\begin{array}{l}\text { Obat Tradisional/Herbal : } \\
\text { - } \quad \text { Minum Rebusan Daun } \\
\text { Jambu biji } \\
\text { - } \quad \text { Minum Teh Jahe dengan } \\
\text { Madu } \\
\text { - } \\
\text { Minum Air Kaldu yang } \\
\text { dicampur Garam } \\
\text { - } \\
\text { Minum segelas Air yang } \\
\text { dicampur } 1 \text { sendok teh } \\
\text { Cuka Apel }\end{array}$ \\
\hline
\end{tabular}

Pengetahuan yang diperoleh dari hasil wawancara dan analisa lewat buku dikonversi ke dalam sebuah tabel penyakit dan gejala guna mempermudah proses pencarian solusi. Tabel penyakit dan gejala ini digunakan sebagai pola pencocokan informasi yang dimasukkan oleh pemakai dan basis pengetahuan. Pada tabel 3.3 jenis penyakit dan gejala $=$ Salmonellosis terdapat 3 jenis penyakit yang ditunjukan oleh P1, P2,P3 dan 25 gejala yang ditunjukkan oleh G1,G2,...,G25. Berikut ini adalah tabel 3.3 yaitu tabel gejala dan jenis penyakit Salmonellosis (penyakit akibat bakteri Salmonella) serta nilai bobot atau nilai tingkat kepercayaan (nilai belief) dan nilai plausability masing-masing gejala terhadap ketiga penyakit di atas yang diderita pasien.

Tabel 3. Tabel Penyakit dan Gejala Salmonellosis

\begin{tabular}{|c|c|c|c|c|c|c|}
\hline Kode & $\begin{array}{l}\text { Nama } \\
\text { Gejala }\end{array}$ & P1 & $\mathbf{P 2}$ & P3 & Bel & Plaus \\
\hline G1 & Lemas/Lesu & $\mathrm{X}$ & $\mathrm{X}$ & $\mathrm{X}$ & 0,3 & 0,7 \\
\hline G2 & $\begin{array}{l}\text { Mual, } \\
\text { muntah }\end{array}$ & $X$ & $\mathrm{X}$ & $X$ & 0,3 & 0,7 \\
\hline G3 & $\begin{array}{l}\text { Perut / Perut } \\
\text { Kram }\end{array}$ & $X$ & $\mathrm{X}$ & $X$ & 0,3 & 0,7 \\
\hline G4 & $\begin{array}{l}\text { Sakit } \\
\text { Kepala/ } \\
\text { pusing }\end{array}$ & $X$ & $\mathrm{X}$ & & 0,5 & 0,5 \\
\hline G5 & $\begin{array}{l}\text { Demam/ } \\
\text { Panas }\end{array}$ & $X$ & $\mathrm{X}$ & & 0,6 & 0,4 \\
\hline G6 & $\begin{array}{l}\text { Mulut } \\
\text { Kering, } \\
\text { Bibir pecah- } \\
\text { pecah }\end{array}$ & $X$ & $\mathrm{X}$ & $X$ & 0,2 & 0,8 \\
\hline G7 & $\begin{array}{l}\text { Perut } \\
\text { Kembung }\end{array}$ & $\mathrm{X}$ & $\mathrm{X}$ & $X$ & 0,3 & 0,7 \\
\hline
\end{tabular}


Jurnal Pseudocode, Volume VI Nomor 1, Februari 2019, ISSN 2355-5920, e-ISSN 2655-1845 www.ejournal.unib.ac.id/index.php/pseudocode

\begin{tabular}{|c|c|c|c|c|c|c|}
\hline G8 & $\begin{array}{l}\text { Ruam di } \\
\text { tubuh }\end{array}$ & $\mathrm{X}$ & & & 0,5 & 0,5 \\
\hline G9 & $\begin{array}{l}\text { Feses Encer } \\
\text { dan } \\
\text { berlendir }\end{array}$ & $\mathrm{X}$ & $X$ & & 0,8 & 0,2 \\
\hline G10 & $\begin{array}{l}\text { BAB > 4x } \\
\text { Sehari }\end{array}$ & $X$ & $X$ & & 0,7 & 0,3 \\
\hline G11 & $\begin{array}{l}\text { Suhu Tubuh } \\
\text { Naik Turun }\end{array}$ & $X$ & & & 0,7 & 0,3 \\
\hline G12 & $\begin{array}{l}\text { Merancau/ } \\
\text { menggigau }\end{array}$ & $\mathrm{X}$ & & & 0,4 & 0,6 \\
\hline G13 & Perut Mulas & $\mathrm{X}$ & $\mathrm{X}$ & & 0,5 & 0,5 \\
\hline G14 & Nadi Lemah & $\mathrm{X}$ & & & 0,3 & 0,7 \\
\hline G15 & $\begin{array}{l}\text { Smabelit/ } \\
\text { Konstipasi }\end{array}$ & & & $X$ & 0,6 & 0,4 \\
\hline G16 & $\begin{array}{l}\text { Feses } \\
\text { Berdarah }\end{array}$ & & & $X$ & 0,8 & 0,2 \\
\hline G17 & $\begin{array}{l}\text { Titer Widal } \\
\text { Antigen } \\
\mathrm{H} / \mathrm{O} / \mathrm{H}-\mathrm{A}<= \\
1 / 160\end{array}$ & & & $\mathrm{X}$ & 0,9 & 0,1 \\
\hline G18 & $\begin{array}{l}\text { Sakit saat } \\
\text { Buang Air } \\
\text { Besar } \\
\end{array}$ & & & $\mathrm{X}$ & 0,4 & 0,6 \\
\hline G19 & Batuk kering & & $\mathrm{X}$ & & 0,3 & 0,7 \\
\hline G20 & $\begin{array}{l}\text { Penurunan } \\
\text { berat badan }\end{array}$ & $X$ & & $X$ & 0,4 & 0,6 \\
\hline G21 & $\begin{array}{l}\text { Kehilangan } \\
\text { nafsu makan }\end{array}$ & $X$ & $X$ & $X$ & 0,3 & 0,7 \\
\hline $\mathrm{G} 22$ & $\begin{array}{l}\text { Mengalami } \\
\text { Linglung }\end{array}$ & $X$ & & & 0,2 & 0,8 \\
\hline G23 & $\begin{array}{l}\text { Nyeri dan } \\
\text { sakit pada } \\
\text { otot }\end{array}$ & $X$ & & & 0,4 & 0,6 \\
\hline $\mathrm{G} 24$ & $\begin{array}{l}\text { Feses yang } \\
\text { dihasilkan } \\
\text { banyak }\end{array}$ & & $X$ & & 0,6 & 0,4 \\
\hline G25 & Haus terus & & $\mathrm{X}$ & & 0,4 & 0,6 \\
\hline
\end{tabular}

d. Gejala 4 yang dipilih: Sering $\mathrm{BAB}(\mathrm{BAB}>4 \mathrm{x}$ sehari), mendukung penyakit $\mathrm{P} 2, \mathrm{P} 3$.

Langkah-langkah perhitungan adalah:

Terlebih dahulu, tentukan nilai densitas $(m)$. Awal nilai densitas $(m)$ awal terdiri dari belief dan plausibility.

Gejala 1: Lemas dan Lesu.

Berdasarkan Tabel 3 relasi antara gejala dengan penyakit serta nilai densitas gejala untuk mendiagnosis penyakit akibat bakteri Salmonella maka diperoleh: $m 1 \quad\{P 1, \quad P 2, \quad P 3\}=0,3$ Selanjutnya merujuk pada rumus 1 sehingga diperoleh nilai plausibility $m 1\{\theta\}=1-0,3=0,70$.

Gejala 2: Demam atau Panas

Berdasarkan tabel 3 relasi antara gejala dengan penyakit serta nilai densitas gejala untuk mendiagnosis penyakit akibat bakteri Salmonella maka diperoleh: $m 2\{P 1, P 3\}=0,60$. Selanjutnya merujukan pada rumus 1 sehingga diperoleh nilai plausibility $m 2\{\theta\}=1-0,6=0,40$.

\section{IMPLEMENTASI}

Fakta-fakta (gejala-gejala) yang ada maka perlu untuk melakukan analisis metode dempster shafer dimana terdapat suatu nilai probabilitas densitas berdasarkan gejala yang diberikan user pada saat diagnosis dilakukan. Pada contoh berikut ini, diasumsikan bahwa gejala yang diambil merupakan gejala dari pakar. Berikut adalah gejala yang sudah dipilih serta kode-kode penyakit yang berhubungan dengan gejala yang dipilih (gejala yang dijawab "YA").

a Gejala 1 yang dipilih: Lemas dan Lesu, mendukung penyakit $\mathrm{P} 1, \mathrm{P} 2, \mathrm{P} 3$.

b. Gejala 2 yang dipilih: Demam atau panas, mendukung penyakit P1, P3.

c. Gejala 3 yang dipilih: Feses Berdarah, mendukung penyakit P3.

Untuk mengetahui hasil diagnosis penyakit yang disebabkan bakteri Salmonella ini, maka dilakukan pengujian proses diagnosis pada aplikasi android. Proses pengujian sistem berupa jawaban dari pertanyaan-pertanyaan gejala yang di jawab "YA" atau "TIDAK" oleh user berdasarkan gejala yang dirasakannya.dan setelah proses konsultasi selesai dilakukan, maka sistem menampilkan hasil diagnosis berupa kemungkinan penyakit yang diderita.

Pada halaman konsultasi, ditampilkan pertanyaan gejala-gejala yang akan dijawab user, pada pengujian ini gejala-gejala yang dirasakan user atau gejala yang dijawab "YA" antara lain lemas/lesu, demam atau panas, feses berdarah dan sering BAB (lebih dari 4x sehari). 
Jurnal Pseudocode, Volume V Nomor 2, September 2018, ISSN 2355-5920, e-ISSN 2655-1845 www.ejournal.unib.ac.id/index.php/pseudocode

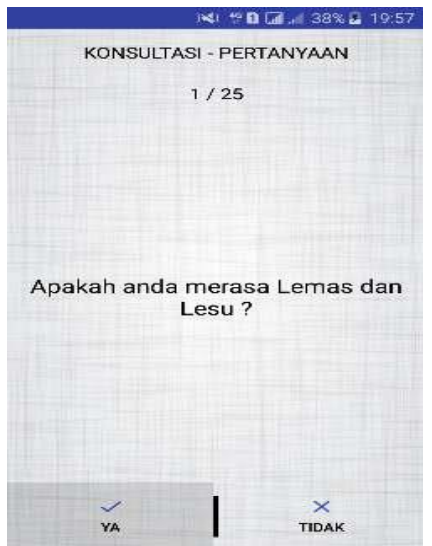

Gambar 1. Gejala lemas yang dijawab "YA" (dirasakan) user

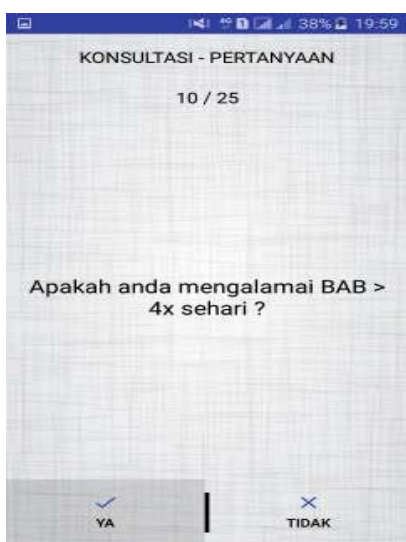

Gambar 2. Gejala sering BAB yang dijawab "YA"

(dirasakan) user

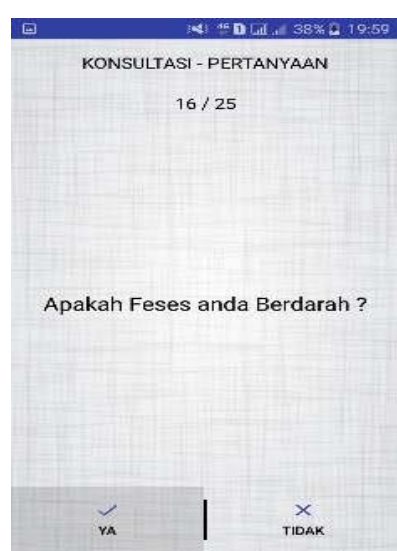

Gambar 3. Gejala feses berdarah yang dijawab "YA"

(dirasakan) user

Ketika semua pertanyaan gejala-gejala telah dijawab user, maka sistem akan melakukan penelusuran penyakit dan akan keluar hasil diagnosis berupa persentase kemungkinan penyakit yang diderita oleh user beserta dengan solusi dan obat penanganannya. Seperti pada

Gambar 4 berikut ini:

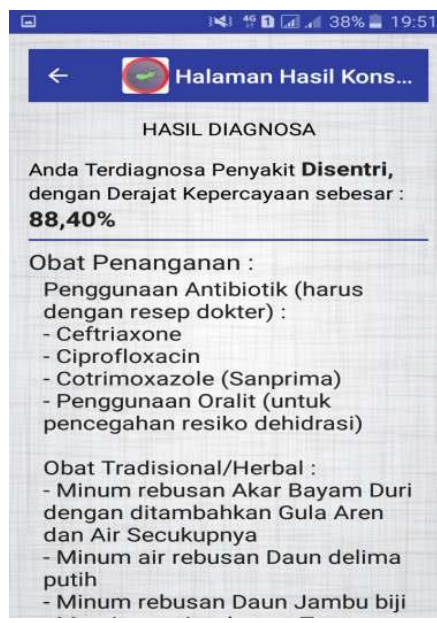

Gambar 4. Halaman hasil diagnosis

Hasil diagnosis dari sistem ini telah sesuai dengan perhitungan manual di bagian analisis metode Dempster-Shafer yaitu menghasilkan diagnosis penyakit disentri dengan derajat kepercayaan sebesar $88,40 \%$.

\section{KESIMPULAN}

Berdasarkan hasil pembahasan di atas, maka penulis menarik beberapa kesimpulan sebagai berikut:

1. Dengan aplikasi sistem pakar diagnosis penyakit akibat bakteri Salmonella ini user bisa mendiagnosis penyakit yang disebabkan oleh bakteri Salmonella berdasarkan keluhan atau gejala yang dirasakan oleh pasien dan menampilkan derajat kepercayaannya dari suatu penyakit.

2. Penelusuran gejala penyakit dilakukan dengan menggunakan metode Dempster-Shafer, dimana metode ini bekerja membandingkan semua gejala penyakit yang diderita oleh user. Hasil dari perbandingan ini diambil probabilitas/ derajat kepercayaan penyakit tertingginya. 
Jurnal Pseudocode, Volume VI Nomor 1, Februari 2019, ISSN 2355-5920, e-ISSN 2655-1845

www.ejournal.unib.ac.id/index.php/pseudocode

3. Dengan sistem pakar ini user juga bisa mendapatkan solusi atau saran pengobatan dari suatu penyakit dengan lebih mudah dan cepat.

\section{REFERENSI}

[1] Ruen, Afriani. 2012. Implementasi Forward Chaining untuk Diagnosis Penyakit Jantung. Skripsi. Universitas Negeri Gorontalo, Gorontalo.

[2] Kusrini. 2008. Aplikasi Sistem Pakar. Andi: Yogyakarta.

[3] Kusumadewi, Sri. 2003. Artificial intelligence I (Teknik dan Aplikasinya). Graha Ilmu: Bandung.

[4] Sulistyohati, Aprilia dan Taufiq Hidayat. 2008. Aplikasi Sistem Pakar Diagnosis Penyakit Ginjal dengan Metode Dempster- Shafer.Seminar Nasional Aplikasi Teknologi Informasi. Yogyakarta.

[5] Dayan Sinaga, M dan Br. Sembiring, N S. 2016. Penerapan Metode Dempster Shafer Vol 2. No 2. Hal 94-107. 